\title{
アルミニウム合金の孔食に及ぼす有機系食品添加物の影響
}

\author{
加藤 彰*，高木章嘉*，吉原佐知雄 ${ }^{*}$, 系井康彦 ${ }^{* *}$, 神戸 哲***, 佐藤栄一 ${ }^{*}$
}

\section{Effect of Organic Food Additives on Pitting Corrosion of Aluminum Alloys}

\author{
Akira KATO*, Akiyoshi TAKAKI*, Sachio YOSHIHARA*, \\ Yasuhiko ITOI*", Satoshi KAMBE*** and Eiichi SATO*
}

\begin{abstract}
The effects of organic food additives on pitting corrosion of aluminum alloys were studied in a neutral solution of sodium chloride. The advance of corrosion was estimated by time variation of the rest potential, anodic and cathodic polarization curves and polarization resistance. Pit depth was evaluated with an optical microscope and photoacoustic spectroscopy (PAS) was newly applied to evaluate the spatial distribution of corrosion pits.

Results obtained were as follows.

1) Organic substances that showed an inhibiting effect, decreasing the maximum pit depth, were : for 3003 alloy DL-thioctic acid, caffein anhydride and L-tryptophan; for 5052 alloy casein ; and for 6063 alloy pyridoxine hydrochloride and hydantoin.

2) In the presence of an organic substance as pitting corrosion inhibitor, obtained corrosion potential at $\mathrm{pH} 7$ shifted to the noble side, and these results support the evaluated results for the maximum pit depth.

In an acid solution of $\mathrm{pH} 3$, obtained corrosion current decreased in the presence of the organic substance.

These results suggests the possibility of an inhibitive effect inside the pits as well as outside the pits.
\end{abstract}

Key Words : Aluminum Alloy, Pitting Corrosion, Organic Inhibitor, Photoacoustic Spectroscopy

\section{1. 緒 言}

アルミニウム合金の孔食に対するインヒビターとして, 多くの無機・有機物質が用いられている ${ }^{1)}{ }^{2)}$ 。しかし, それらのインヒビターにあ幾つかの問題がある。例えば, クロム酸塩等の無機インヒビターに対する公害規制 ${ }^{3)}$.4) や, 一個のピットが貫通することによる化学装置等の機 能損失等である。

本研究ではこれらの点を考慮し，塩化物イオンを含む 中性水溶液中のアルミニウム合金に対するインヒビター として有効な物質を, 無公害の有機系食品添加物約 70 種 類の中より見いだした。その抑制効果は，アルミニウム 合金に生じるピットの最大深さや孔食電位の測定によっ て評価した。

また腐食評価法の 1 つとして, 近年, 光音響的及び光 電気化学的手法を用いた鉄や銅に対するin situ観測に よる酸化物の生成状況やインヒビターの抑制効果を光電

* 宇都宮大学工学部（干321 杤木県宇都宮市石井町2753）

Fac. of Eng., Utsunomiya Univ. (2753, Ishii-machi, Utsunomiya-shi, Tochigi 321)

** 小山工業高等専門学校 (广323 栃木県小山市中久喜771) Oyama National College of Tech. (771, Nakaguki, Oyama-shi, Tochigi 323)

*** 帝京大学理工学部（行320 栃木県宇都宮市長岡町西北山 1189-4)

Fac. of Sci. and Eng., Teikyo Univ. (1189-4, Nishikitayama, Nagaoka-machi, Utsunomiya-shi, Tochigi 320)
流の変化で評価した研究などが報告されつつある ${ }^{5) ~ 8) 。 ~}$ そこで光音響分光法 (以下PASと略す) により，ピッ トの生成による表面の凹凸の評価を試みたので併せて報 告する。

\section{2. 実験方法}

\section{1 試料, 試験夜}

用いた試料は，JIS規格に基づく3003合金（板厚0.4 $\mathrm{mm}$ )，5052合金（板厚 $1.2 \mathrm{~mm}$ ）, 6063合金（板厚 1.2 $\mathrm{mm}$ ）である。それらの合金の分析值を表 1 に示す。こ れらの試料は, 前処理としてアセトン脱脂後, $10 \mathrm{wt} \%$ 水酸化ナトリウム水溶液 $\left(55^{\circ} \mathrm{C}, 1 \mathrm{~min}\right)$ でエッチング し, 水洗した後に $20 \mathrm{wt} \%$ 硝酸（室温，90s）で中和・ス マット除去を行い, その後水洗した。

試験液は, イオン交換水により作製した $3 \%$ 塩化ナト リウム水溶液と, $10^{-4} \mathrm{~mol} / \mathrm{dm}^{3}$ の有機物質を添加した 水溶液を用いた。 $\mathrm{pH}$ 調整はイオン強度を合わせるため に $0.513 \mathrm{~mol} / \mathrm{dm}^{3}$ の塩酸及び水酸化ナトリウム水溶液で

Table 1 Chemical composition of aluminum alloys (wt\%).

\begin{tabular}{c|c|c|c|c|c|c|c|c|c|c}
\hline Alloy & $\mathrm{Si}$ & $\mathrm{Fe}$ & $\mathrm{Cu}$ & $\mathrm{Mn}$ & $\mathrm{Mg}$ & $\mathrm{Cr}$ & $\mathrm{Ni}$ & $\mathrm{Zn}$ & $\mathrm{Ti}$ & $\mathrm{Al}$ \\
\hline 3003 & 0.27 & 0.63 & 0.16 & 1.1 & 0.0042 & 0.0022 & 0.26 & 0.0072 & 0.0114 & bal. \\
\hline 5052 & 0.094 & 0.24 & 0.067 & 0.024 & 2.3 & 0.0077 & 0.0020 & 0.0097 & 0.0174 & bal. \\
\hline 6063 & 0.42 & 0.18 & 0.0281 & 0.0141 & 0.49 & 0.0136 & -57 & 0.0255 & 0.0145 & bal. \\
\hline \multicolumn{7}{c|}{ * ppm }
\end{tabular}


Table 2 Organic food additives tested as inhibitor.

\begin{tabular}{l|l|l}
\hline Saccharin & $\beta$-Carotene & Sodium L-Glutamate \\
\hline Caffein Anhydride & Linoleic Acid & Aspartame \\
\hline L-Tryptophan & Riboflavin & $\begin{array}{l}\text { Pyridoxine } \\
\text { Hydrochloride }\end{array}$ \\
\hline D-Fructose & Adipic Acid & $:$ \\
\cline { 1 - 2 } Folic Acid & Casein & $:$ \\
\hline DL-Thioctic Acid & Hydantoin & \\
\hline
\end{tabular}

行った。また, 浸せき試験の試験液には, 促進剂として 塩化第二銅を $0.26 \mathrm{~g} / \mathrm{dm}^{3}$ 添加して行った。

\section{2 インヒビター}

約70種類の有機物質 ${ }^{9) \sim 11}$ を，インヒビターとして試み た。その一例を表 2 に示す。

\section{3 漫せき試験}

浸せき試験液 $100 \mathrm{~mL}$ に対して，約 $40 \times 20 \mathrm{~mm}$ に切断 した試料 1 枚をビーカー底部に静置し, 大気開放下, 室 温で $5 ， 10 ， 15 ， 20$ 日間各々 3 種類の合金に対して試験 した。その試料は, 露出面が $5 \times 5 \mathrm{~mm}$ にるようにマ スキングテープ及びエポキシ樹脂により被覆した。

\section{4 ピット深さ测定}

浸せき試験後, 試料の腐食生成物をリン酸ークロム酸 混液 $\left(85 \% \mathrm{H}_{3} \mathrm{PO}_{4} 35 \mathrm{~mL}+\mathrm{CrO}_{3} 20 \mathrm{~g} / \mathrm{dm}^{3}, 95^{\circ} \mathrm{C}\right.$, $5 \mathrm{~min}$ ）により除去した後, 読取顕微鏡（ピカ精工， Z 方向のみをデジタル型に改造したPRM- 2 ）を用いて, 各々の試料に対するすべてのピットの深さ及び数を測定 した。またピットの径の測定は, 本研究の主旨が深さ方 向への成長を抑制するインヒビターを見いだすことなの で除外した。

\section{5 電気化学的測定}

測定には, ポテンシオガルバノスタット（北斗電工侏， HA-301), ファンクションジェネレーター（北斗電工 (株)，HB-104)，X-Yレコーダー（横河電機(㑣), TYPE 3036)，X-tレコーダー（横河電機(侏), TYPE3046）を 用いた。

測定条件としては, 浴温が $25^{\circ} \mathrm{C} て ゙, ~ H$ 型セルを用い, 作用極には $50 \times 20 \mathrm{~mm}$ に切断して露出面が $10 \times 10 \mathrm{~mm}$ に なるように被覆したアルミニウム合金板，対極には白金 板, 参照電極には飽和カロメル電極を用いた。電位のス

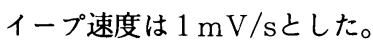

分極曲線の測定は, $\mathrm{pH} 3$ 及びpH 7 に調整した試験液 中で行い, 自然電極電位の経時変化の測定は, $\mathrm{pH} 7$ の 試験液中で 4 時間行った。分極抵抗法では, 腐食計（北 斗電工(侏)，HK103）を用い30分間行った。そしてStern の式(1)を応用した式(2)より，腐食抵抗 $R$ を求めた。

$$
\begin{aligned}
& I_{\text {corr }}=K \Delta I / \Delta E \cdots \cdots \cdots \\
& \Delta E / \Delta I=K / I_{\text {corr }}=R .
\end{aligned}
$$

しRへ換算した。

\section{6 PAS}

PASによるピットの評価は, 腐食生成物を除去した 試料に対して行った。検出器は外部からの振動や電気的 ノイズを防ぐため鉄製のシールドボックス内に置いた。 光源にはアルゴンイオンレーザー (ILT5000, Ion Laser Technology, マルチライン) を用い, ライトチョッパー (5584, NF ELECTRONIC INSTRUMENTS) で断 続し, 試料表面に照射した。PAシグナルは, 試料裏面 に高真空用シリコーングリース（DOW CORNING） をカップリング剂としてホフマン式ピンチコックにより 圧着した圧電素子PZT（TOKIN, NPM, N-21, 直径 $10 \mathrm{~mm}$, 厚さ $1 \mathrm{~mm}$, 円板型）により電気信号に変換し, チョッパーからの参照信号に同期した信号をシングルフェ イズロックインアンプ（5600, NF ELECTRONICINSTRUMENTS）によりロックイン検出した。

測定は, 直前に試料をリン酸一クロム酸混液により酸 化物を除去し，一定時間後にレーザーを照射し，定常状 態になった後に変調周波数を $4 \sim 4000 \mathrm{~Hz}$ に変化させ行っ た。これは, 低い変調周波数では式(3)に示す熱拡散長は 大きくなり，より深いところの情報を得ることができ， 高い変調周波数のときは熱拡散長は小さくなり, 表面に 近いところの情報が得られるという概念 ${ }^{12)} に$ 基づく。

$$
\begin{aligned}
& \mu_{\mathrm{s}}=\alpha /(\pi \cdot f)^{1 / 2} \cdots \cdots \cdots \cdots \cdots \cdots \cdots \cdots \cdots \cdots \cdots \cdots \cdots \cdots \cdots \cdots \cdots \cdots(3)^{13)}
\end{aligned}
$$

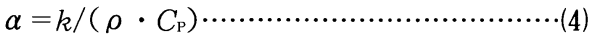

ここで,

$$
\begin{array}{ll}
\mu_{\mathrm{s}}: \text { 熱拡散長 }[\mathrm{cm}] & \alpha: \text { 熱拡散率 }\left[\mathrm{cm}^{2} / \mathrm{s}\right] \\
f: \text { 变調周波数 }\left[\mathrm{s}^{-1}\right] & k: \text { 熱伝導度 }\left[\mathrm{J} \cdot \mathrm{cm}^{-1} \cdot \mathrm{K}^{-1} \cdot \mathrm{s}^{-1}\right] \\
\rho: \text { 物質密度 }\left[\mathrm{g} \cdot \mathrm{cm}^{-3}\right] & C_{\mathrm{P}}: \text { 比熱 }\left[\mathrm{J} \cdot \mathrm{g}^{-1} \cdot \mathrm{K}^{-1}\right]
\end{array}
$$

\section{3. 結果と考察}

\section{1 読取顥微镜によるピット深さ測定}

3. 1.1 最大ピット深さ

20日間の浸せき試験の結果, 最大ピット深さが無添加 の場合よりあ小さくなった有機物質の構造式等を図 1 に 示す。そして図 2 に, それらの有機物質の最大ピット深 さの経時変化を示す。3003合金ではDLーチオクト酸, 無水カフェイン, Lートリプトファン, 6063合金ではピ リドキシン塩酸塩, ヒダントインを添加したとき，15日 経過以降で無添加の場合と比べて最大ピット深さに差が 生じ，5052合金に対するカゼインは，浸せき初期の段階 から差が生じていることがわかる。これは，これらの物 質がピット内のアノード反応を抑制し，ピットの深さ方 向への成長を抑制していると推定できる。また, インヒ ビター効果のない物質，ここでは一例として3003合金に おける葉酸を示すが, 最大ピット深さは常に無添加の場 合より大きくなった。

腐食計によって $\Delta I=1 \mu \mathrm{A}$ を与え, $\Delta E$ の応答を測定 
3003

Dt-Thioctic Acid

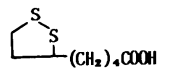

5052

Casein Main component
of protein
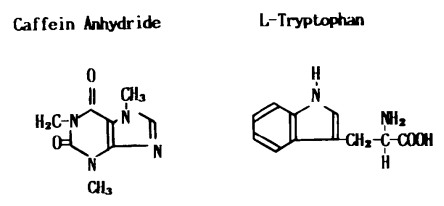

6063

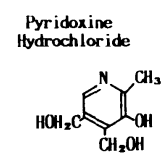

Hydantoin

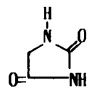

Fig. 1 Structural formulas of substance showed inhibitive effect.

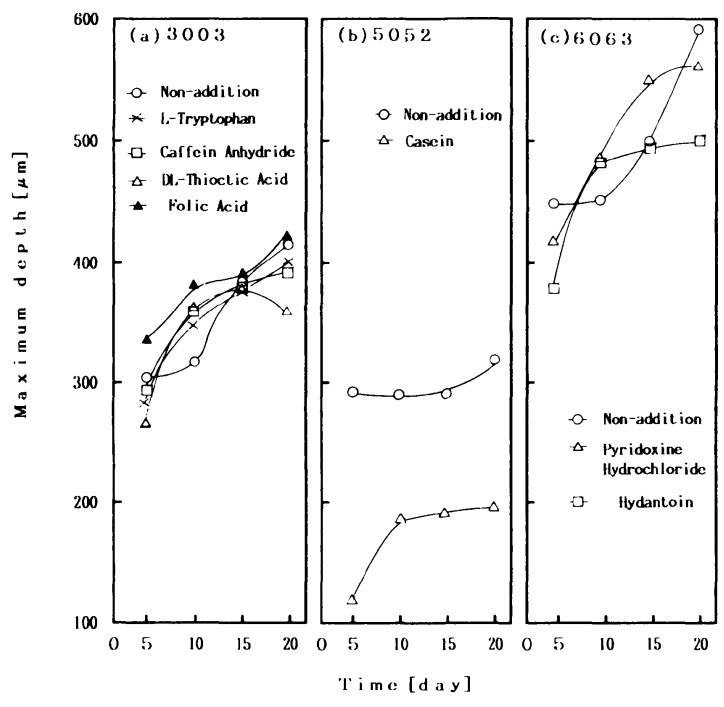

Fig. 2 Time variation of maximum pit depth of (a) 3003, (b) 5052 and (c) 6063 (pH 7 ).

\section{1. 2 ピット深さ分布}

浸せき後20日目の試料に対するピット深さの分布を図 3 に示す。3003合金の場合では，深さ $160 \mu \mathrm{m}$ 以上では 無添加の方が数が少なくなっている。これは, 幾つかの ピットが重なり径の大きいピットとなるために, 観測し た数としては少なくなった。5052合金の場合では，力ゼ インを添加したほうがピットの深さ方向への成長を抑制 していることがわかる。6063合金の場合では，ヒダント インはどのサイズのピットあ無添加の場合と同等である が，ピリドキシン塩酸塩では，深いピットから浅いピッ トまでその数は無添加の場合よりも若干少ない傾向を示 した。

\section{2 電気化学的測定}

3. 2.1 分極曲線による評価

3. 1でインヒビター効果を示した物質について，その 有効性を確かめるため電気化学的測定を行った。使用し たインヒビターの孔食に対する抑制効果の結果を表 3 に
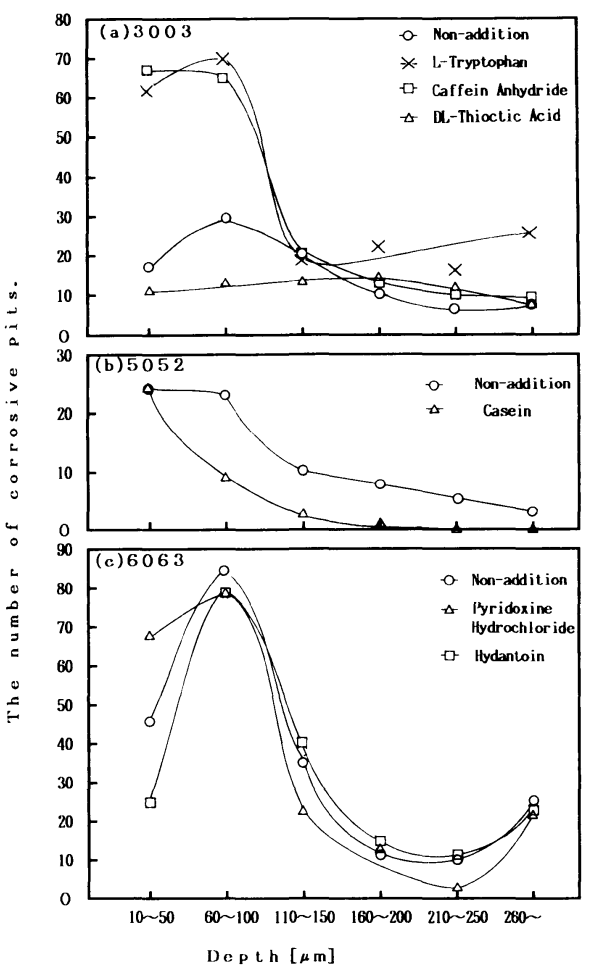

Fig. 3 Depth profile for corrosive pits of (a) 3003, (b) 5052 and (c) 6063 after 20 days ( $\mathrm{pH} 7$ ).

示し，自然電極電位の経時変化を図 4 に示す。

まず孔食電位について考えた。3003合金に対するチオ クト酸及び6063合金に対するピリドキシン塩酸塩の場合 を除いて，表 2 に示した物質については孔食電位が無添 加の場合よりあ約 $5 \sim 20 \mathrm{mV}$ 貴な電位を示した。これは 局部アノード反応を抑制したことになり，いわゆる耐孔 食性が良いと考えられる。この結果は，ピット深さ測定 の結果との対応が見られる。

ここで, アルミニウムのピット内部の $\mathrm{pH}$ は $2 \sim 3$ と 報告されている例 ${ }^{14)}$.15) 屯あるので，この条件に近似的な pH 3 の試験液中に抢ける腐食電位と腐食電流密度を測 定してみた。3003合金ではDLーチオクト酸及びLート リプトファンを添加した場合の腐食電位は, 無添加の場 合とほぼ同等とみられるが無水力フェインを添加した場 合には，むしろ貴へシフトしている。5052合金に対して カゼインを添加した場合も同様の結果になった。しかし, 6063合金では，ピリドキシン塩酸塩及びヒダントインを 添加すると腐食電位は早にシフトした。腐食電流密度は, 3003合金に対するLートリプトファンの場合を除けば表 3 に示した物質の腐食電流密度は無添加の場合よりも小 さい值を示しており，ピット内部においても腐食を抑制 する効果は生ずる可能性があると考えられる。

そこでェバンス図で考えれば，上述した中で腐食電位 
Table 3 Obtained pitting corrosion potential ( $\mathrm{pH} 7$ ), diffusion limitting current density (pH 7 ), rest potential ( $\mathrm{pH} 7$ ), corrosion potential $(\mathrm{pH} 3)$, and corrosion current density ( $\mathrm{pH} 3$ ) of each alloys in the $3 \% \mathrm{NaCl}$ solution with and without inhibitor.

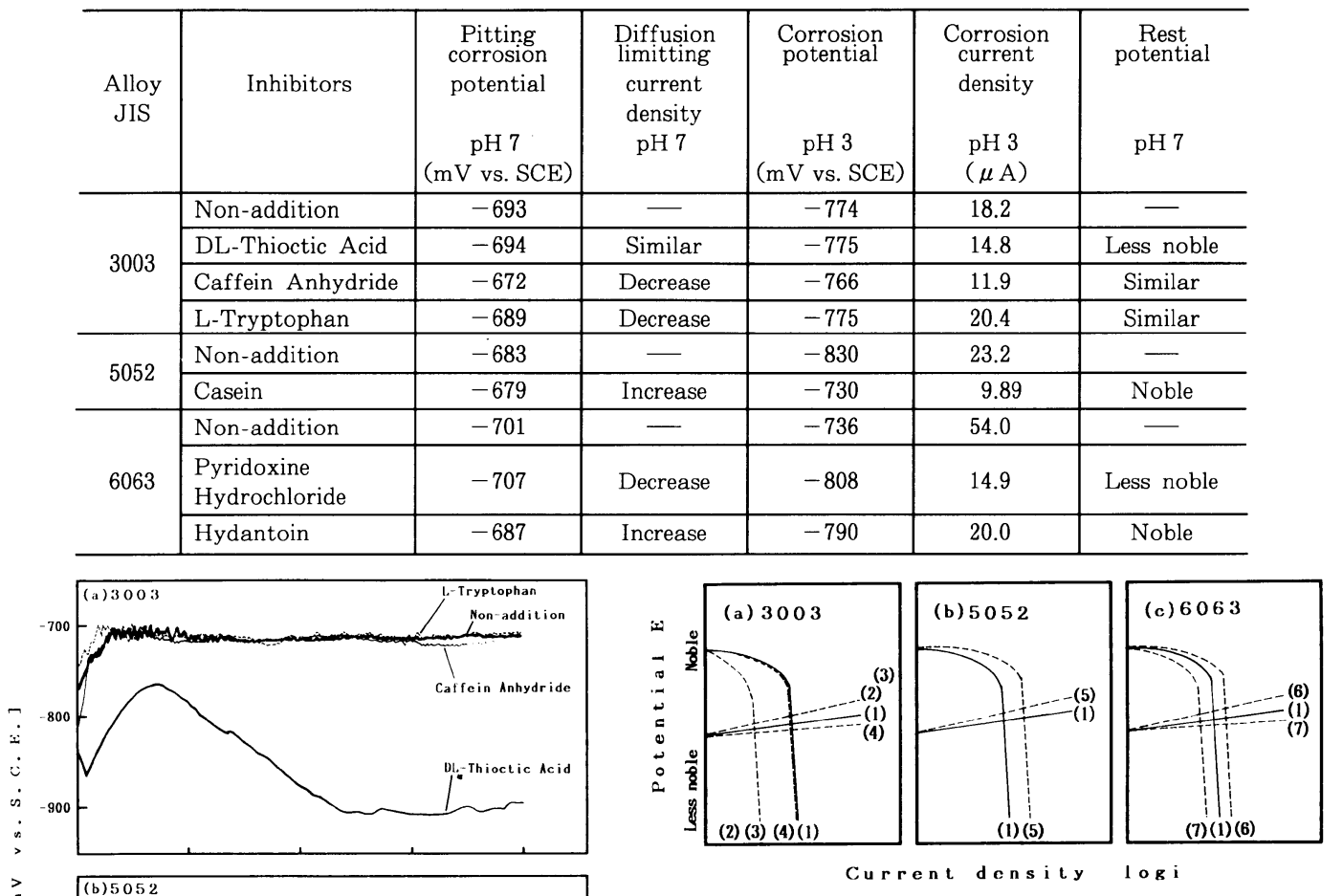

Fig. 5 Schematic illustration showing the relation between the local polarization curves of (a) 3003 , (b) 5052 and (c) 6063 .
(1) Non-addition
(2) Caffein Anhydride
(3) L-Tryptophan
(4) DL-Thioctic Acid
(5) Casein
(6) Hydantoin
(7) Pyridoxine Hydrochloride

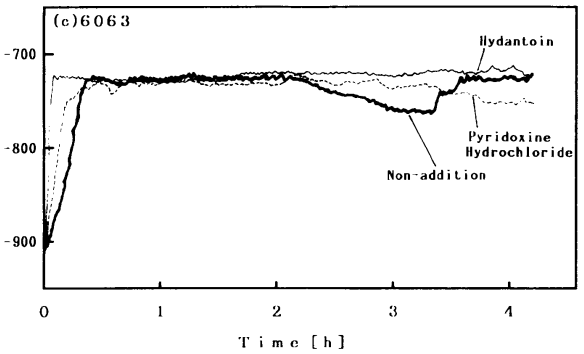

い外表面を含めた部分の耐食性を図 5 のモデル図より考 えてみた。3003合金に対する無水カフェイン(2)及びLトリプトファン(3)の場合, 局部アノード・局部カソード 反応ともに，分極が大きくなれば腐食電位も貴になると 考えられるが, 分極の程度が極めて小さいために電位は ほとんど同じになったと思われる。DL一チオクト酸(4) の場合は，局部アノード反応はわずかに分極するが局部 カソード反応が無添加の場合と同等なため電位は卑になっ たと考えられる。5052合金に対するカゼイン(5)の場合は, 局部アノード反応がわずかに分極するが局部カソード反 応が大きく復極するために, 全体の腐食電流密度は大き くなり電位は貴にシフトしていった。6063合金に対する ヒダントイン(6)の場合，局部アノード反応はわずかに分 極し局部カソード反応は復極するために, 電位は貴にシ フトし全体の腐食電流密度は大きくなる。ピリドキシン 塩酸塩(7)の場合は, 局部アノード反応はわずかに復極し 局部カソード反応は分極するために, 電位は卑にシフト し全体の腐食電流密度は小さくなる。これらのことから, ピットの深さ方向への成長を抑制する物質がすべて, 外 


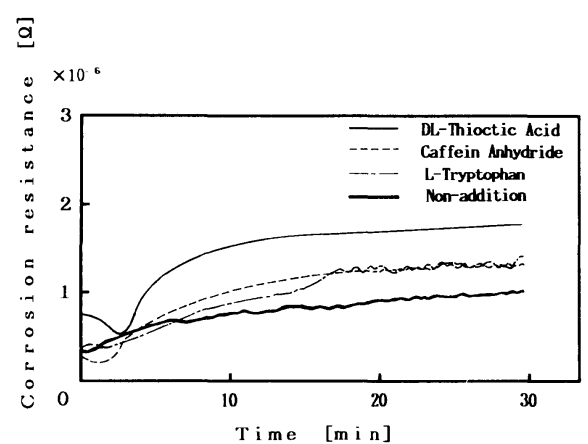

Fig. 6 Time variation of corrosion resistance for aluminum alloy $3003(\mathrm{pH} 7)$.

表面の腐食をあ抑制するとは限らないことがわかる。

\section{2.2 分極抵抗法による評価}

ここまでが局部的な腐食に対する検討であったが，ピッ 卜内部を含めた外表面に対する効果すみる必要があると 考え，分極抵抗法による評価を行った。分極抵抗法によ る腐食抵抗の測定結果の一例を図 6 に示す。最大ピット 深さを小さくするインヒビタ一効果のあった物質は，ど れ屯無源加の場合よりあ腐食抵抗は大きくなり，換言す れば腐食速度が減少したことになる。これは，これらの 物質がピット内部とピット外表面ともに腐食を抑制して いることを示している。また初期の膨らみは，破壊され た不動態皮膜が修復され，再不動態化を起こしたための 現象と思われる。

\section{3 PASによるピットの評価}

次に, PASをピット深さの評価法の一つとして用い ることができないかと考え，まず，in situ 観測の前駆 段階としての基礎的デー夕を得るための測定を試みた。 その結果の一例を図 7 に示す。ここでPAシグナル強度 は，変調周波数が $4 \mathrm{~Hz}$ のときには熱の伝わる範囲内で ピットの影響は無視できると考え，このときのPAシグ ナルを 1 と規格化し比較した。

ピットが存在しない（浸せき試験を行っていない）試 料(6)とピットが存在する試料(1)〜 (5)の相対PAシグナル 強度を比較すると, 明らかにピットの存在する試料のほ うが相対PAシグナル強度は大きくなっている。そして インヒビター効果を示した物質(3)〜(5)は，無添加の場合 (2)の相対PAシグナル強度よりも全体的に小さくなった。 これらのことは，ピットの深いあのは反射して再び試料 表面外に出てくる光の割合が小さく，レーザー光を多く 吸収するためであると考察できるが，詳しい解釈につい ては検討中である。

\section{4. 結 論}

1 ）約70種類の有機物質の中で，3003合金に対しては $\mathrm{DL}$-チオクト酸, 無水カフェイン及びLートリプト

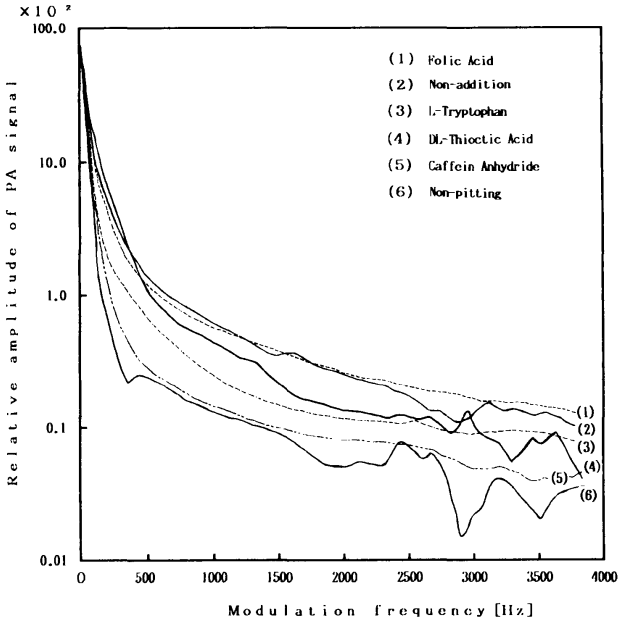

Fig. 7 Dependence of relative amplitude of PA signal on modulation frequency for aluminum alloy 3003 .

ファン，5052合金に対してはカゼイン，6063合金に対し てはピリドキシン塩酸塩及びヒダントインが最大ピット 滐さを小さくするインヒビター効果を示した。

2 ）ピットの深さ方向への成長を抑制する物質を添加し た場合, 分極曲線から得られる孔食電位は貴ヘシフト し，浸せき試験の結果のインヒビタ一効果を支持した。 また, $\mathrm{pH} 3$ の酸性試験液にお゙いても，これらの物質 を添加した場合の分極曲線から得られる腐食電流密度は 小さくなった。このことからピット内部でも腐食抑制の 可能性があると思われる。

(1989-11-24 受理)

\section{文献}

1) H. Böhni and H. H. Uhling ; J. Electrochem. Soc., 116, 906 (1969)

2) W. J. Rudd and J. C. Scully ; Corros. Sci., 20, 611 (1980)

3) 松島 厳; 電気化学, 54, 378 (1986)

4 ）藤井晴一; 金属表面技術, 35，222（1984）

5 ) M. Seo, X. C. Jing and N. Sato ; Werkst. Korros., 39, 583 (1988)

6 ) A. Fujishima, Y. Nagae and K. Honda ; J. Electroanal. Chem., 162, 241 (1984)

7 ) A. Aruchamy, G. Zhou and A. Fujishima ; J. Electroanal. Chem., 244, 333 (1988)

8 ) J. A. Gardella, Jr., D. -Z. Jiang, W. P. McKenna and E.M. Eyring ; Appl. Surf. Sci., 15, 36 (1983)

9 ) 石館守三, 谷村顕雄 監修; 食品添加物公定書解説書, p. 1 (廣川書店, 1987)

10）桜井芳人, 川城 嚴 ; 食品別添加物用覧, p.596（化学工業 社, 1970)

11）新村壽夫 ; 食品添加物の生化学と安全性, p.433（地人書館, 1979)

12）澤田嗣郎, 織田昌平, 塈尾邦彦; 光音響分光法とその応用PAS, p.111（学会出版センター, 1982)

13）澤田嗣郎；化学と工業, 48, 869 (1989)

14）当摩 建, 山田一雄; 軽金属, $30 ， 85$ (1980)

15）当摩 建 ; 金属表面技術，32，521（1981） 